\title{
Knowledge as an Object of Transfer Cooperation between Enterprises Foreign and Domestic
}

\author{
Magdalena Byczkowska ${ }^{\dagger 1}$, Anna Majzel ${ }^{1}$, \\ ${ }^{1}$ Department of of Economics, The Jacob of Paradyz University, Poland
}

\begin{tabular}{l}
\hline ARTICLE INFO \\
\hline Article History \\
\\
\hline JEL Classifications \\
E 22, F2 1, F23
\end{tabular}
ABSTRACT

Purpose:

The aim of the considerations undertaken in this article was to identify the issues concerning the scope and effects of cooperation between companies with foreign capital and domestic entities of foreign direct investment and to identify the scale of impact of foreign companies operating in Poland on domestic entities in the sphere of knowledge.

Design/methodology/approach:

The main survey was conducted in 2017 and covered a group of 120 foreign enterprises from the list of the largest foreign investors in Poland, drawn up by Polish Information and Foreign Investment Agency (PAIiIZ). As part of the conducted survey, a targeted selection was applied, which guaranteed a selection corresponding to specific survey criteria. The measurement tool was a survey questionnaire, which contained both open and closed questions. In the case of the majority of closed questions, it was possible to add own answers to the proposed variants, not provided by the Author.

Findings:

By penetrating domestic economies, they bring not only such an important capital, but a whole package of added values, which are worth mentioning, among others: knowledge, managerial skills or an increase in the level of innovativeness of enterprises.

The importance of foreign direct investment, as one of the most important factors in the modernisation of the domestic economy, is all the greater the scarcity of domestic financial resources prevents actions to improve the country's competitiveness, but also when it is not possible to create innovations on one's own. An opportunity to bridge the gap in economic development (including the technology gap) of less developed or developing countries is

Keywords: knowledge, foreign direct investments precisely the activity of international companies, which are a form of foreign direct investment. This is because they bring with them the transfer of technology and knowledge, which are stimuli for innovation and development of the modern economy.

Research limitations/implications:

One of the most basic and uncontrolled constraints is the limited access to data related to the survey - (data protection by enterprises), - original sample selection - The group of investors was selected by comparing the list of the Polish Information and Foreign Investment Agency (PAIiIZ) - the 500 largest foreign investors in Poland, and the list of "Fortune" magazine - the 500 largest corporations in the world classified by value of income. Apart from direct impact on the economy of a given country, foreign investment may also have an indirect impact (portfolio investment) - the method of quantification of data collected by financial institutions has often made it impossible to distinguish between these two streams of foreign capital.

Originality/value:

The study carried out by the author of the dissertation is in itself a significant contribution to the development of FDI methodology in Central and Eastern Europe. The most significant results representing the scientific novelty of the dissertation include the following elements: determining the impact of FDI on the formation of business systems related to the broadly understood knowledge and skills of the company - including the management and organization system, quality management, and employment.

${ }^{\dagger}$ Corresponding Author: Magdalena Byczkowska

Email: magdabyczkowska@wp.pl 


\section{Introduction}

Modern technology, knowledge and investment in people are nowadays important, if not the most important factors for the long-term development of enterprises. Investments in these aspects of increasing corporate value significantly determine their national competitive advantage. Not without significance in this case are the links and cooperation of domestic companies with companies with foreign capital. It is their expansion that is attributed, among others, to filling the gap of capital shortage, transfer of modern technologies, knowledge and skills or diffusion of modern organizational solutions. Therefore, the aim of this study was to identify the scale of cooperation between domestic and foreign companies, as well as the degree of impact of this cooperation in terms of knowledge and skills transfer.

The article uses indirect measurement methods (research questionnaire), comparison and literature review. The choice of these methods was determined primarily by the type of research materials available. The method of indirect measurement was used to diagnose the transfer of knowledge to domestic enterprises, while the comparative method was used primarily to confront different points of view related to the topic of the role of foreign capital. Whereas the literature review was carried out in order to characterize the latest achievements related to the undertaken issues, which were presented in the scientific publications in question.

\section{Implementation of the study}

The main survey was conducted in 2017 and covered a group of 120 foreign enterprises from the list of the largest foreign investors in Poland, drawn up by Polish Information and Foreign Investment Agency (PAIiIZ). As part of the conducted survey, a targeted selection was applied, which guaranteed a selection corresponding to specific survey criteria.

The measurement tool was a survey questionnaire, which contained both open and closed questions. In the case of the majority of closed questions, it was possible to add own answers to the proposed variants, not provided by the Author. Entrepreneurs marked their chosen answer variants with an appropriate sign or assigned them a specific scale of importance by assigning the given values. The data obtained in this way were developed on the basis of the number of answers given to a given question.

The questionnaire consisted of three main parts and the so-called tag, where respondents were asked to provide basic information about the company.

The main parts of the questionnaire are:

- Part I - Cooperation of undertakings.

- Part II - Innovative activities and technology transfer.

- Part III - Transfer of knowledge.

The research process included the following methodological approach:

A. desk research - it included the collection and analysis of available information and a review of previous research on the state of innovative potential of entrepreneurship in Poland, as well as the activities of companies with foreign capital in this respect; the research also provided information used in building research questions;

B. questionnaire survey - in order to maximise the effectiveness of the survey, the designed survey tool was previously checked in a pilot study, which allowed to verify the accuracy and comprehensibility of the questions included in the questionnaire, as well as to verify the correctness of its general structure.

As a result of the actions taken, 45 correctly completed research questionnaires (out of 120) were returned, which means a return of $37.5 \%$ and allows the results to be generalised to the whole community. Among the 45 companies that took an active part in the survey were large companies with an average employment of 565 people. In the surveyed sample, the majority of companies with foreign capital and those with a majority share of foreign capital (over $80 \%$ ) prevailed. Information on the share of foreign capital in the surveyed group of companies is presented in Table 1.

Table 1: Share of foreign capital in the surveyed group of enterprises

\begin{tabular}{|c|c|c|}
\hline Share of foreign capital & Number of enterprises & In \% \\
\cline { 2 - 3 } & Absolute & $2,2 \%$ \\
\hline Up to $50 \%$ & 1 & $4,4 \%$ \\
\hline $51 \%-75 \%$ & 2 & $3,9 \%$ \\
\hline $76 \%-90 \%$ & 4 & $35,6 \%$ \\
\hline $91 \%-99 \%$ & 16 & $46,7 \%$ \\
\hline $100 \%$ & 21 & $2,2 \%$ \\
\hline No answer & 1 & $100 \%$ \\
\hline Total & 45 & \\
\hline
\end{tabular}

Source: (Researcher, 2017) 
The vast majority of investors who engaged capital in the surveyed companies came from the European Union (81\%). The majority of them were investors from the European Union (81\%): Germany, France, Sweden, Holland. From outside the EU structures, capital came from Switzerland and the USA (Table 2).

Table 2: Country of origin of foreign investor of enterprises constituting the research sample

\begin{tabular}{|c|l|c|c|}
\hline Number & Country & \multicolumn{2}{|c|}{ Number of enterprises } \\
\cline { 3 - 4 } & & Absolute & in $\%$ \\
\hline 1. & Germany & 17 & 37,8 \\
\hline 2. & France & 8 & 17,8 \\
\hline 3. & Holland & 6 & 13,3 \\
\hline 4. & Italy & 4 & 8,9 \\
\hline 5. & Switzerland & 3 & 6,7 \\
\hline 6. & USA & 3 & 6,7 \\
\hline 7. & Denmark & 1 & 2,2 \\
\hline 8. & Spain & 1 & 2,2 \\
\hline 9. & UK & 1 & 2,2 \\
\hline 10. & Austria & 1 & 2,2 \\
\hline Total & Total & 45 & 100 \\
\hline
\end{tabular}

Source: (Researcher, 2017)

Due to large diversification of location of enterprises with foreign capital participation in Poland, the number of questionnaire questionnaires per each voivodship was drawn with a probability proportional to the number of active enterprises in a given layer. The number of conducted interviews in particular voivodships is presented in Table 3.

Table 3: Percentage distribution of the surveyed enterprises in particular voivodships

\begin{tabular}{|l|c|l|l|l|c|}
\hline \multicolumn{1}{|c|}{ Voivodships } & $\%$ & \multicolumn{1}{c|}{ Voivodships } & $\%$ & Voivodships & $\%$ \\
\hline dolnośląskie & $8 \%$ & mazowieckie & $17 \%$ & świętokrzyskie & $2 \%$ \\
\hline kujawsko-pomorskie & $3 \%$ & opolskie & $2 \%$ & warmińsko-mazurskie & $5 \%$ \\
\hline lubelskie & $4 \%$ & podkarpackie & $4 \%$ & wielkopolskie & $11 \%$ \\
\hline lubuskie & $5 \%$ & podlaskie & $2 \%$ & zachodniopomorskie & $4 \%$ \\
\hline łódzkie & $7 \%$ & pomorskie & $5 \%$ & świętokrzyskie & $2 \%$ \\
\hline małopolskie & $8 \%$ & śląskie & $13 \%$ & & \\
\hline TOTAL & \multicolumn{5}{|c|}{$100 \%$} \\
\hline
\end{tabular}

Source: (Researcher, 2017)

Additionally, when interpreting the results, the classification of provinces into regions with different levels of investment attractiveness was used. Each voivodship belongs to one of four classes of voivodship determined by the degree of investment risk. Below is the Investment Risk Map, on the basis of which the classification was made. Class $\mathrm{A}$ - provinces of highest investment attractiveness Class B - provinces of medium investment attractiveness Class C provinces of low investment attractiveness Class D - provinces of lowest investment attractiveness (Table 4, Map 1).

Table 4: Investment attractiveness of Poland

\begin{tabular}{|c|c|c|c|c|c|c|c|c|c|c|c|c|c|c|c|c|}
\hline $\begin{array}{l}\text { Voivod } \\
\text { ships }\end{array}$ & 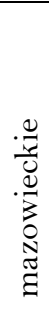 & $\frac{\frac{n}{\pi}}{\frac{\pi}{\pi}}$ & $\begin{array}{l}\frac{0}{\frac{\pi}{2}} \\
\frac{0}{0} \\
0 \\
\frac{0}{0} \\
\frac{0}{0} \\
\frac{0}{3}\end{array}$ & $\begin{array}{l}\frac{0}{\pi} \\
\frac{\pi}{\tilde{O}} \\
\frac{\vec{w}}{0} \\
\stackrel{\Xi}{0} \\
\frac{0}{0}\end{array}$ & 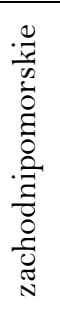 & 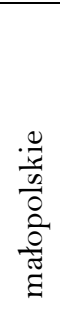 & $\begin{array}{l}\frac{0}{\frac{\pi}{\pi}} \\
\frac{2}{2} \\
\frac{0}{\Xi}\end{array}$ & $\begin{array}{l}\frac{0}{\frac{0}{4}} \\
\frac{1}{0} \\
-1\end{array}$ & 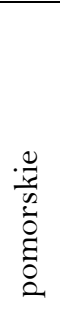 & 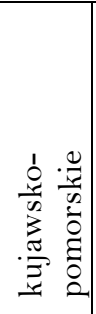 & $\begin{array}{l}\frac{0}{\frac{\pi}{2}} \\
\frac{\pi}{0} \\
\frac{0}{0}\end{array}$ & 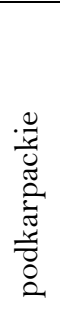 & 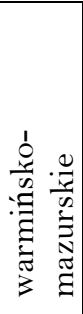 & 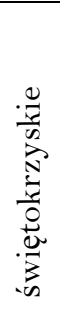 & $\begin{array}{l}\frac{0}{\pi} \\
\frac{\pi}{12} \\
\frac{\pi}{7} \\
0 \\
0 \\
2\end{array}$ & $\begin{array}{l}\frac{0}{\frac{\pi}{n}} \\
\frac{0}{0} \\
\frac{0}{\Xi}\end{array}$ \\
\hline Class & A & A & B & B & B & $\mathrm{C}$ & $\mathrm{C}$ & $\mathrm{C}$ & $\mathrm{C}$ & $\mathrm{C}$ & $\mathrm{C}$ & $\mathrm{D}$ & $\mathrm{D}$ & $\mathrm{D}$ & $\mathrm{D}$ & $\mathrm{D}$ \\
\hline
\end{tabular}

Source: (1) 


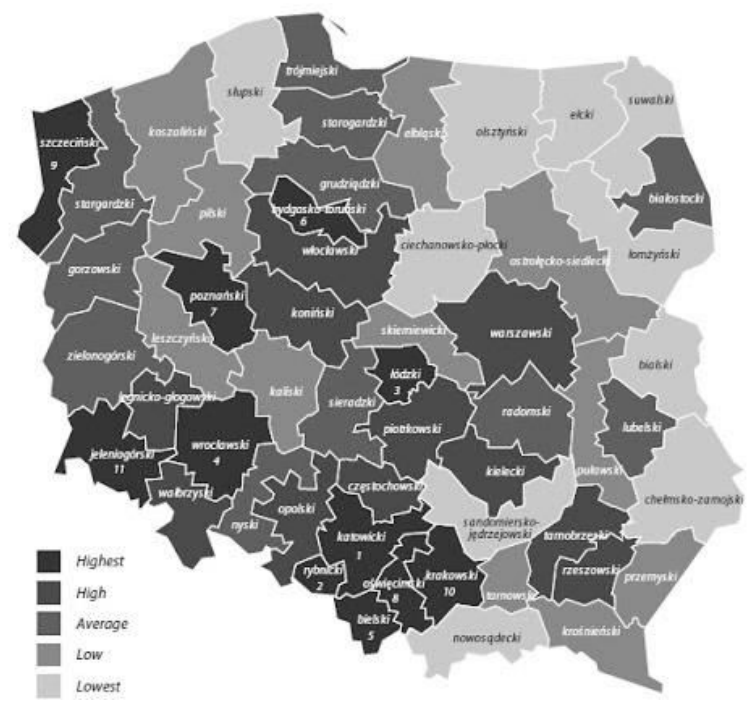

Map 1: Investment attractiveness of Poland Source: (1)

Foreign enterprises surveyed represented mainly the industrial sector - industrial processing (51\%), financial intermediation $(20 \%)$ and trade and repairs $(13.3 \%)$. The activities of the remaining $15.7 \%$ of respondents focused mainly on transport, warehouse management and communications, construction and hotel and catering activities (Figure 1)

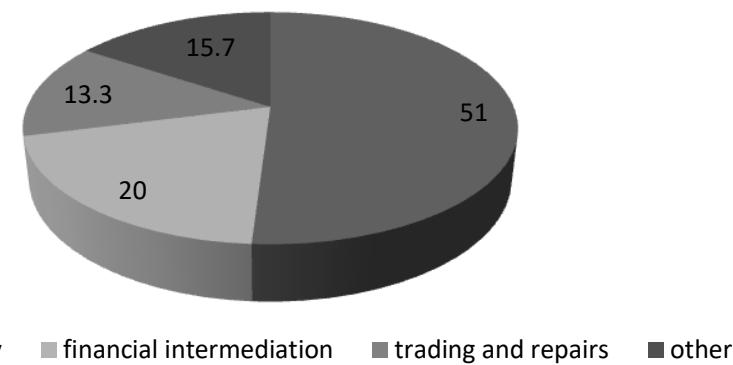

Figure 1: Structure of the surveyed enterprises by sections of the Polish Classification of Activities (in \%) Source: Research Data (2017)

Taking into account the above, foreign companies representing the following sections of the Polish Classification of Activities took part in the survey - Table 5 .

Table 5: Structure of the surveyed enterprises

\begin{tabular}{|l|l|}
\hline SECTION D & MANUFACTURING \\
\hline SECTION F & CONSTRUCTION \\
\hline SECTION G & TRADING AND REPAIRS \\
\hline SECTION H & HOTELS AND RESTAURANTS \\
\hline SECTION I & TRANSPORT, STORAGE AND COMMUNICATION \\
\hline SECTION J & FINANCIAL INTERMEDIATION \\
\hline SECTION K & REAL ESTATE, RENTING AND SERVICES RELATED TO DOING BUSINESS \\
\hline
\end{tabular}

Source: (Researcher, 2017)

Among the surveyed foreign entities, the vast majority were new enterprises, created from scratch. They prevailed both in the industrial and service sectors, dominating the sections of the economy represented in the study. Much less often foreign investors built new enterprises together with Polish capital, creating the so-called joint venture. The form of entry into the Polish market is presented in Table 6.

Table 6: Form of entry into the Polish market

\begin{tabular}{|l|l|l|}
\hline \multirow{2}{*}{ Description } & Number of enterprises \\
\cline { 2 - 3 } & Absolute & In \% \\
\hline Greenfield investments & 31 & 68,9 \\
\hline Joint- venture & 7 & 15,5 \\
\hline Acquisition & 2 & 4,4 \\
\hline
\end{tabular}




\begin{tabular}{|l|l|l|}
\hline No data & 5 & 11,1 \\
\hline Total & 45 & 100 \\
\hline
\end{tabular}

Source: (Researcher, 2017)

The obtained results allow for the implementation of the set objectives, and in particular the cooperation of foreign enterprises with the entities of the country of deposit, the innovative activity of enterprises with foreign capital and the transfer of knowledge and skills by them.

\section{Knowledge as a subject of business cooperation transfer}

Knowledge transfer is the process of finding, assessing, validating, applying, improving knowledge and creating routines. According to W. Grudzewski and I. Hejduk (Grudzewski, Hajduk, 2004), the use of knowledge is not possible without its transfer, and in turn, knowledge transfer is not possible without its prior location. Location of knowledge is based on reaching people who have the necessary knowledge and are able to transfer it to others without delay. The literature highlights the fact that cooperation between companies strengthens the sharing of knowledge. The tools used in this process include: training of employees in different organizations, exchange of experienced staff, exchange of documents, diagrams or computer programs, as well as information about the organizational structure. Knowledge transfer between organisations can therefore take place by moving people, technology or structures between cooperating entities (Argote, 1999).

Surveys conducted among a group of foreign companies showed that they were active in activities aimed at knowledge transfer between their closest partners. Companies in the vast majority (nearly 80\%) declared that they had established and respected the rules of cooperation with their closest partners, which facilitated knowledge transfer, especially during the initial operation on the market Companies were also willing to share knowledge with their direct partners $(73 \%)$, which means that despite the high degree of formalisation, these companies were ready to exchange knowledge as part of cooperation- Figure 2.

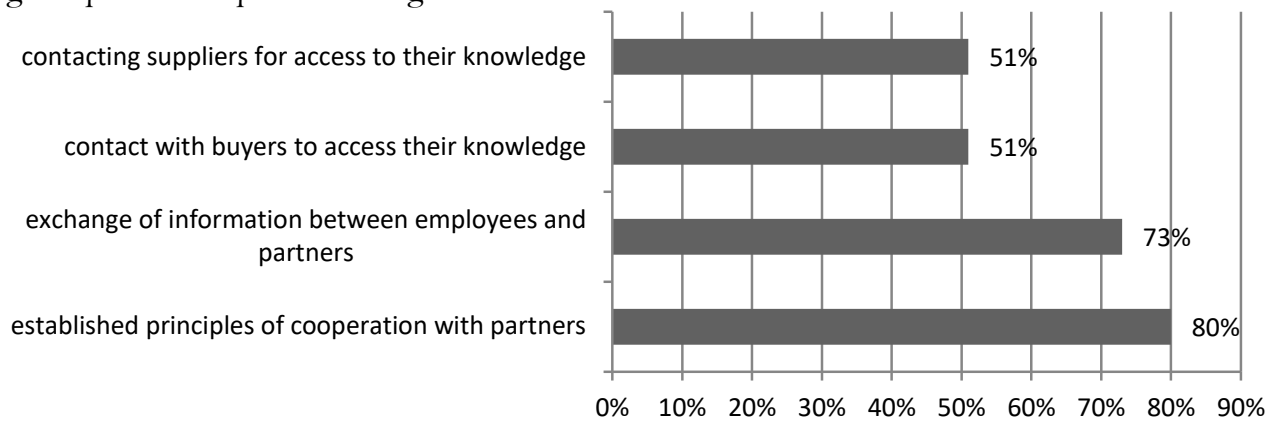

Figure 2: Active in knowledge transfer activities (in \%)

Source: Research Data (2017)

Among the directions of cooperation, within the framework of knowledge transfer, of foreign enterprises with the enterprises of the country, there are: organization of occasional events for employees and direct cooperators (44.4\%), inviting direct cooperators to participate in the research $(37.8 \%)$, conducting consultations, transferring technical information, sharing know-how (31.1\%), participation in projects organized by direct cooperators $(31.1 \%)$, exchange of information between employees and further cooperators. (26.2\%), contacts with competitors in order to access their knowledge $(22.2 \%)$, sharing know-how and technologies with direct partners $(22.2 \%)$, visits of partners in order to present the principles of the company's operation (20\%), organization of courses, trainings attended by employees of partner companies (20\%) and sharing of commercial information (11.1\%)--Figure 3.

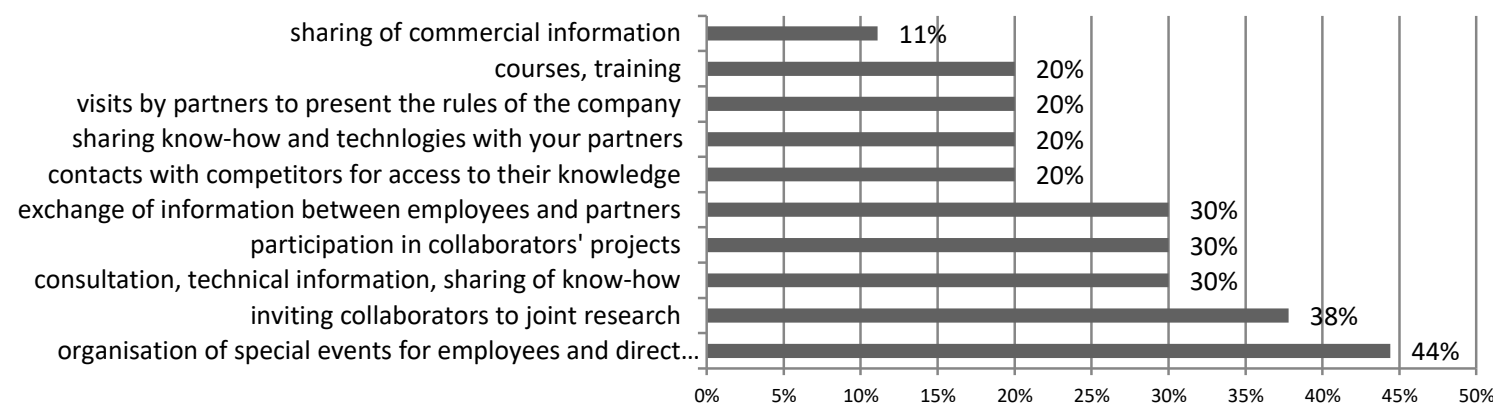

Figure 3: Areas of cooperation between partner enterprises in the framework of knowledge transfer (in \%) Source: Research Data (2017)

Within the framework of knowledge transfer between foreign and domestic enterprises, the methods and techniques used in this respect were also identified. They were evaluated in terms of: comprehensibility, effectiveness, and usefulness of the knowledge transferred through them. The average assessment of the importance attributed by the respondents to the methods and techniques in question is presented in Table 7 . The higher the average value and 
closer to a 5.0 rating, the companies surveyed attributed more importance to the method. On this basis, the methods and techniques considered to be key in terms of knowledge transfer were identified (mean score of at least 4 ) and those of lesser importance (mean score below 4 ).

Table 7: Importance attributed to knowledge transfer methods and techniques

\begin{tabular}{|l|c|}
\hline \multicolumn{1}{|c|}{$\begin{array}{c}\text { KNOWLEDGE TRANSFER METHODS AND } \\
\text { TECHNIQUES }\end{array}$} & $\begin{array}{c}\text { FOREIGN COMPANIES } \\
\text { FACE-TO-FACE CONSULTATIONS }\end{array}$ \\
\hline CALL CENTRES & 4,31 \\
\hline TRAININGS & 4,28 \\
\hline CONTACT BY ELCTRONIC MAIL & 4,28 \\
\hline CCESS TO TECHNICAL DOCUMENTATION & 4,24 \\
\hline E-LEARNING & 3,95 \\
\hline JOINT RESEARCH & 3,93 \\
\hline ACCESS TO EXPERTISE ON THE WEBSITE & 3,75 \\
\hline MEETINGS IN EMPLOYEE (TASK FORCE) TEAMS & 3,62 \\
\hline
\end{tabular}

The scale of answers: 1 - I do not agree, 2 - I partially disagree, 3 - I do not have an opinion, 4 - I partially agree, 5 - I agree

Source: Research Data (2017)

The qualitative research carried out has shown that the knowledge transfer methods and techniques used demonstrate the complexity and diversity of their application. The most important knowledge transfer methods and techniques were identified as those that take the form of direct or indirect contact with the "source of knowledge": direct consultations, telephone consultations, participation in training courses and e-mail contact. Less crucial were identified as: access to technical documentation, e-learning, joint research, access to expertise on the website or meetings in teams..

The research carried out also showed that the imported knowledge had an impact on the company's functioning and management process.

The impact on the company's management and organisation system was confirmed by as much as $80 \%$ of the companies surveyed. According to them, the most changes took place in the sphere of quality management (36\%). Slightly fewer changes were observed in the sphere of research management and the development of the company $(25 \%)$, as well as in the sphere of information management (25\%). Changes in personnel management were indicated by $20 \%$ of the surveyed entities. According to the respondents, the least changes occurred in the area of occupational health and safety management (11\%) (Figure 4).
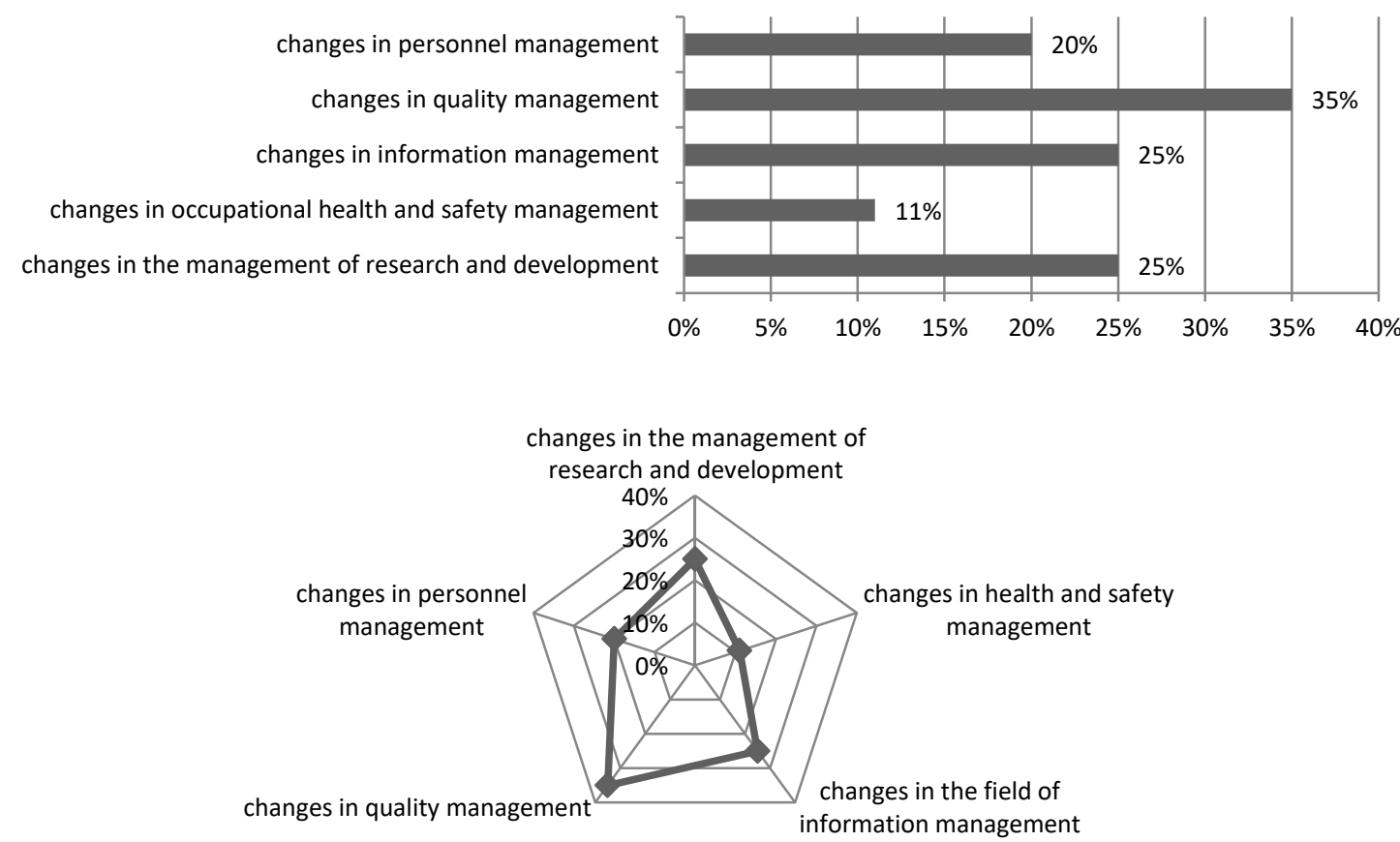

Figure 4: Company management and organisation system and foreign capital inflow (in \%)

Source: Research Data (2017)

In the sphere of quality management, the impact of imported knowledge was visible in processes related to: process and service quality improvement $(40 \%)$, quality certification $(25 \%)$ and in improving the qualifications of personnel responsible for improvement and quality control (23\%)-Figure 5. 

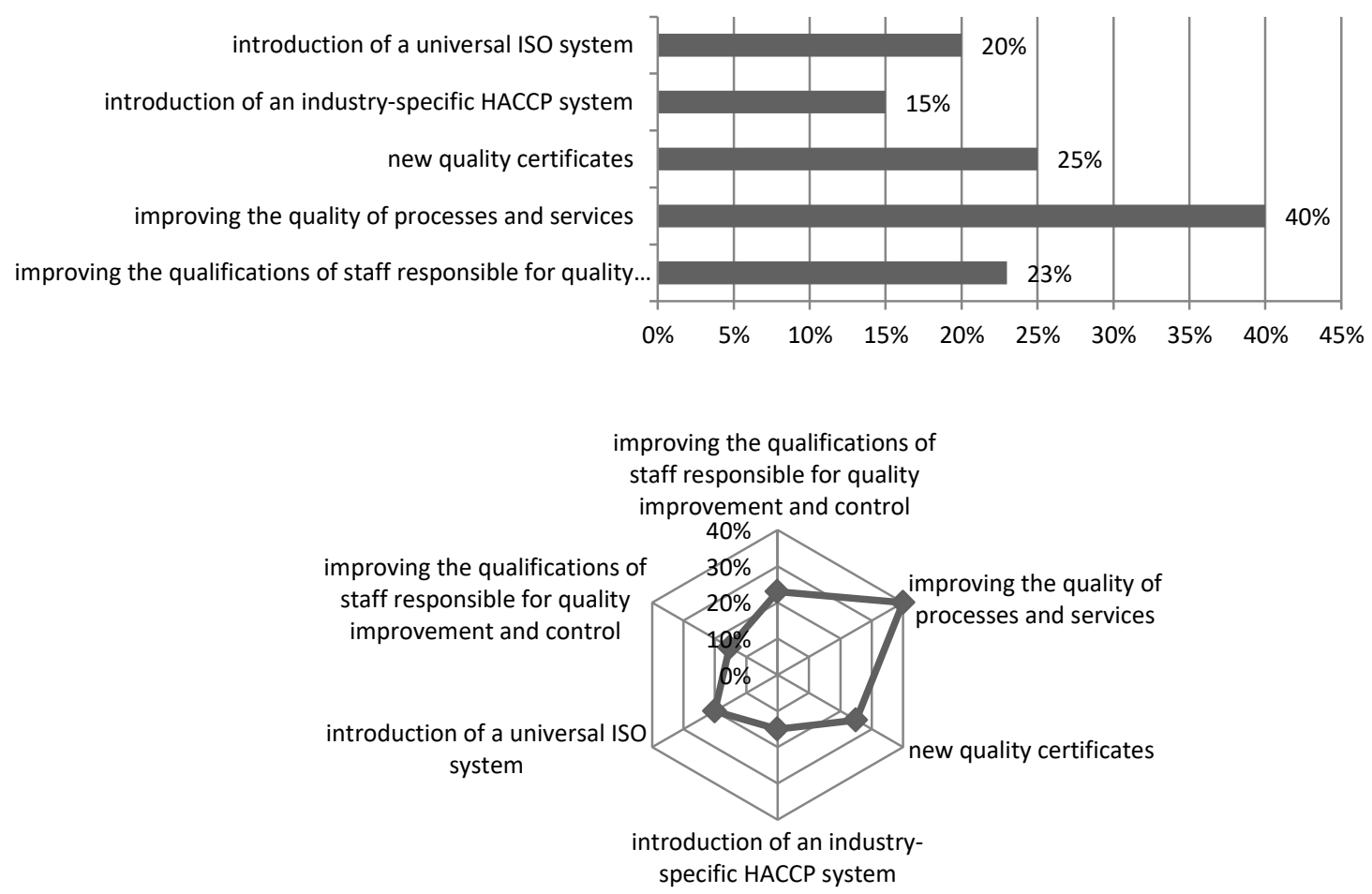

Figure 5: Changes in quality management in the surveyed group of enterprises caused by the inflow of foreign capital (in \%)

Source: Research Data (2017)

On the other hand, in the sphere of information management, which allows for better organization and quicker reaction to all types of problems of the company, the impact of the transferred knowledge concerned mainly: introduction of a more efficient organization of the information management system (25\%), as well as a system responsible for the security of processed data $(23 \%)$ and more efficient satisfaction of the management's information needs (23\%) Figure 6.

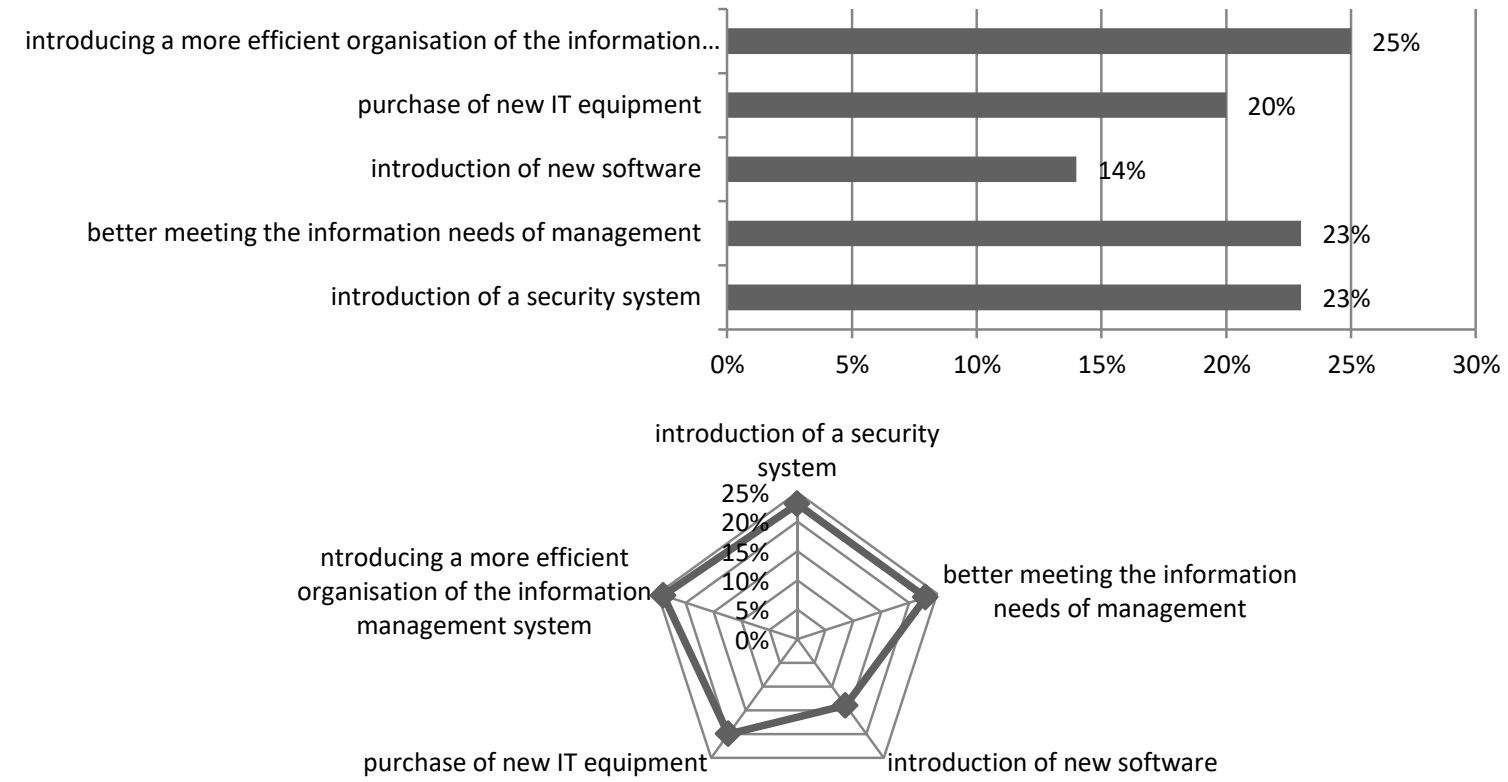

Figure 6: Influence of foreign capital in the form of FDI on changes in the sphere of information management in the enterprise (in \%)

Source: Research Data (2017)

In terms of employment, on the other hand, imported knowledge has influenced primarily: employment policy, labour productivity and the level of qualifications of employees (Figure 7). 

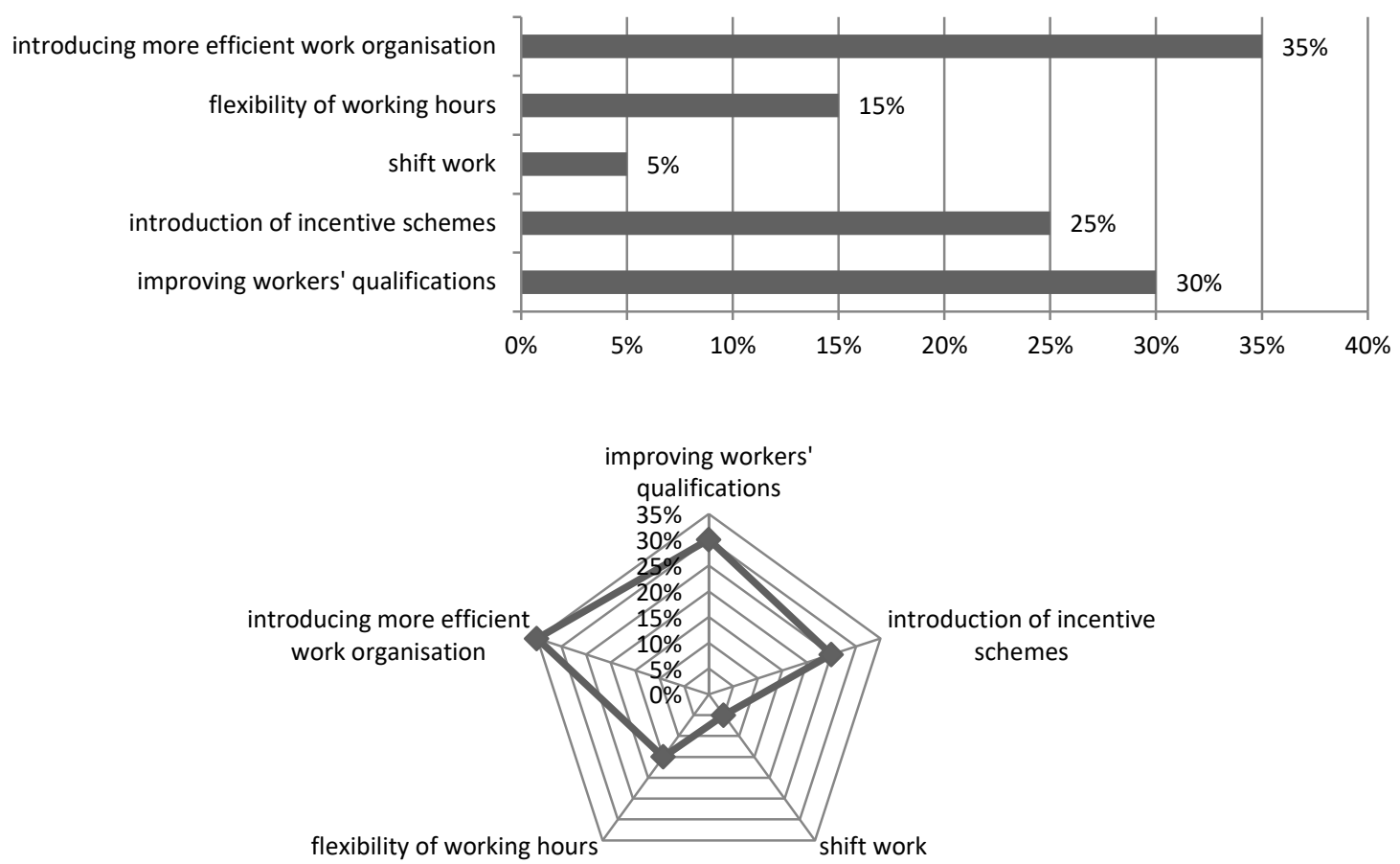

Figure 7: Impact of FDI on the employment policies of the enterprises participating in the survey (in \%) Source: Research Data (2017)

The qualitative research was aimed at illustrating and deepening the analysis of the internationalisation process in the context of activities supporting knowledge transfer. The following conclusions can be drawn from the analysis:

- Foreign companies established contacts with other entities, thanks to which they had access to specific knowledge, which made it easier for them to start up on the market;

- Internationalisation companies have established contacts with suppliers and buyers in order to access their technology and share their knowledge with their closest partners.;

- The most frequently used tools supporting knowledge transfer include: direct consultations or participation in vocational training.;

- Imported knowledge had an impact on particular spheres of business activity: quality management, information management, employment policy;

- Knowledge transfer has had a positive impact on employment policy, in particular on labour productivity and employee qualifications.

\section{Conclusion and Recommendations}

Foreign direct investment plays an important role in the global economy. By penetrating domestic economies, they bring not only such an important capital, but a whole package of added values, which are worth mentioning, among others: knowledge, managerial skills or an increase in the level of innovativeness of enterprises.

The importance of foreign direct investment, as one of the most important factors in the modernisation of the domestic economy, is all the greater the scarcity of domestic financial resources prevents actions to improve the country's competitiveness, but also when it is not possible to create innovations on one's own. An opportunity to bridge the gap in economic development (including the technology gap) of less developed or developing countries is precisely the activity of international companies, which are a form of foreign direct investment. This is because they bring with them the transfer of technology and knowledge, which are stimuli for innovation and development of the modern economy.

It is clear from the research carried out that undertaking and development of cooperation between companies was important for them. This cooperation was desirable because it brought a number of benefits, including: increasing employment, presentation of management organization techniques, forcing qualitative changes through necessary adjustments, co-implementation of new projects, joint training of employees or exchange of commercial information. National business partners were also an important source of information about the local market, competitors and potential customers. This created an opportunity for companies to gain a competitive advantage on the market, as well as to gain knowledge about new solutions that enabled them to increase innovation in future activities.

The results of the research conducted among foreign companies also showed that they established contacts with other entities, thanks to which they had access to specific, unique knowledge, facilitating their initial activity on the market. Companies that were internationalising established contacts with suppliers and buyers in order to have access 
to their technologies, but also shared their knowledge with their closest partners. The most frequently used tools supporting knowledge transfer were: direct consultations or participation in professional trainings, and the imported knowledge had an impact on such spheres of business activity as: quality management, information management, employment policy.

To sum up, it should be stated that the lack of domestic capital significantly limits the possibilities of dynamising the Polish economy. Therefore, it should be postulated that a more favourable investment climate be created, encouraging foreign investors to invest free capital here. It is also advisable to build a system of incentives stimulating, first of all, the inflow of foreign capital to areas having a decisive impact on the development of the economy - creating new jobs, extending the scope of new technologies and modern solutions in the area of management and organisation of economic activity, dynamising exports and, consequently, leading to an improvement in the competitiveness of the global economy.

\section{References}

Atrakcyjność inwestycyjna regionów (2018). PAIH, Warsaw, 34.

Argote L. (1999). Organizational learning. Creating, retaining and transferring knowledge, Springer, 12 1-124.

Bednarczyk J.L., Bukowski S., Misala J. (2009). Globalne rynki finansowe w dobie kryzysu, CeDeWu, Warszawa, 254.

Belniak M.,(2018). Rola klastrów w procesie internacjonalizacji przedsiębiorstw i budowanie ich pozycji konkurencyjnej, w:Uwarunkowania internacjonalizacji przedsiębiorstw w dobie gospodarki przedsiębiorczej (ed.) Wach K., Marjański A., Wydawnictwo Społecznej Akademii Nauk, Łódź- Warszawa, 78-80.

Byczkowska M. (2006). Bezpośrednie inwestycje zagraniczne jako czynnik kształtowania rozwoju regionu, Print Group, Szczecin, $37-38$.

Czerwieniec E. (1990), Zagraniczne inwestycje bezpośrednie w gospodarce krajów wysoko rozwiniętych, Zeszyty Naukowe- Seria II. Prace Doktorskie i Habilitacyjne z. 105. Akademia Ekonomiczna w Poznaniu, Poznań, 99-100.

Ciborowski R., (2013), Wpływ procesów globalizacyjnych na działalność B+R i rozwój technologiczny, w: Idee liberalne w ekonomii 20 lat po śmierci F. von Hayeka, Ciborowski R., Kargol- Wasiluk A., Zalesko M. (ed) (2013),Wydawnictwo Uniwersytetu w Białymstoku, Białystok, 111-112.

Ciborowski R., Kargol- Wasiluk A., Zalesko M. (2013). Idee liberalne w ekonomii 20 lat po śmierci F. von Hayeka, Wydawnictwo Uniwersytetu w Białymstoku, Białystok, 111-112.

Frejtag Mika E., (2009), Architektura finansowa globalnej współpracy na rzecz rozwoju - wyzwania millenijne, w :Globalne rynki finansowe w dobie kryzysu , Bednarczyk J.L., Bukowski S., Misala J. (ed),(2009) CeDeWu, Warszawa, 254.

Grudzewski W., Hejduk I(2004). Zarządzanie wiedzą w przedsiębiorstwie, Diffin, 89-90.

Karaszewski W., (2017). Bezpośrednie inwestycje zagraniczne w wybranych województwach Polski- analiza porównawcza, Wydawnictwo Naukowe UMK, Toruń, 134-138.

Kola- Bezka M., Kuzel M., Sobczak I.(2009). BIZ w województwie kujawsko- pomorskim, WSG, Bydgoszcz, 201-203.

Kużel M.(2005). Zarządzanie wiedzą w korporacjach transnarodowych a proces dyfuzji wiedzy i umiejętności, w: (W. Karaszewski ed.) Bezpośrednie inwestycje zagraniczne w podnoszeniu konkurencyjności polskiej gospodarki, Toruń, 76-80.

Lech M.,(2010). Zdolność oddziaływania korporacji transnarodowych na współczesne stosunki międzynarodowe w dobie procesu globalizacji, w: J. Menkens, T. Gardocka (ed.),(2010) Korporacje transnarodowe, Academika, Warszawa, 23-27.

Macias J., (2010). Nowa strategia transnarodowa korporacji międzynarodowych- globalna standaryzacja i lokalna wrażliwość, Przegląd Organizacji(9), 35-38.

Menkens J., Gardocka T. (2010). Korporacje transnarodowe, Warszawa, 23-27.

Nauka i Technika w 2014 roku, Informacje i opracowania statystyczne (2015). GUS, Warszawa, 121.

Nauka i Technika w 2015 roku, Informacje i opracowania statystyczne (2016). GUS, Warszawa, 132.

Nauka i Technika w 2016 roku, Analizy statystyczne (2018). GUS, Warszawa, Szczecin 123.

Wach K., Marjański A. (2018). Uwarunkowania internacjonalizacji przedsiębiorstw w dobie gospodarki przedsiębiorczej, Wydawnictwo Społecznej Akademii Nauk, Łódź- Warszawa, 78-80. 